\title{
Prediction of Asiatic Acid Derivatives Affinity Against SARS-CoV-2 Main Protease Using Molecular Docking
}

\author{
Ida Musfiroh*, Alia Resti Azura, Driyanti Rahayu \\ Faculty of Pharmacy, Universitas Padjadjaran, Bandung, Indonesia
}

\begin{abstract}
COVID-19 is a pandemic that currently occurs in almost all parts of the world, caused by a new coronavirus species that can infect humans, namely SARS-CoV-2. To date, there is no effective drug to treat COVID-19. There are studies proving that the secondary metabolites of pentacyclic triterpenes have antiviral activity, one of which is asiatic acid. The aims of this study are to obtain the affinity and interactions of asiatic acid derivative structures in inhibiting the main protease of SARS-CoV-2. The research method was molecular docking of asiatic acid and its derivatives against the main protease of SARS-CoV-2 (6LU7) consisting of ligand and receptor preparation, identification of active site, and molecular docking simulation. The results of this study indicate that asiatic acid derivative AA9 has the best affinity in inhibiting the main protease of SARSCoV-2 with binding free energy value $(\Delta G)$ of $-9.90 \mathrm{kcal} / \mathrm{mol}$, compared with favipiravir which has $\Delta G$ value of $-4.58 \mathrm{kcal} / \mathrm{mol}$. AA9 also has an interaction with the main protease of SARSCoV-2 through hydrogen bonds with Gly143. This present study showed that asiatic acid and its derivatives have a higher binding affinities to SARS-CoV-2 main protease compared to favipiravir.
\end{abstract}

ARTICLE HISTORY

Received: June 2020

Revised: July 2020

Accepted :July 2020

Keywords: COVID-19; SARS-CoV-2; asiatic acid; molecular docking

*corresponding author

Email: ida.musfiroh@unpad.ac.id

\section{INTRODUCTION}

COVID-19 was first reported by a number of patients with pneumonia with unknown causes that were epidemiologically related to the animal and seafood market. A new coronavirus was detected in the epithelial cells of the respiratory tract patients, named 2019-nCoV (Zhu et al., 2020) which was later on 11 February 2020 officially changed to severe acute respiratory syndrome coronavirus 2 (SARS-CoV-2 by the International Committee on Taxonomy of Viruses (WHO, 2020).

SARS-CoV-2 is a virus that can cause pneumonia with clinical presentation closely resembles the infection caused by SARS-CoV (Huang et al., 2020). The infection caused by SARS-CoV-2 can cause hyperinflammatory syndrome that occurs due to a cytokine storm from an excessive body response to the existence of SARSCoV-2 (Ozdemir, 2020).

One of the potential drug targets in the treatment of COVID-19 is the main protease $\left(\mathrm{M}^{\mathrm{pro}}\right)$ of SARS-CoV-2 (PDB code 6LU7). $\mathrm{M}^{\text {pro }}$ is a key enzyme in SARS-CoV-2 which plays an important role in the replication and transcription of the virus, which makes it a promising drug target for this virus, if the $\mathrm{M}^{\text {pro }}$ is inhibited it will interfere with the course of the virus replication in the body (Jin et al., 2020).

Utilization of medicinal plants and secondary metabolites of plants can be an alternative (Yang et al., 2018). Based on the research of Zhao et al. (2014), pentacyclic triterpenes are a group of promising secondary plant metabolites showing antiviral activity. In that research, asiatic acid became one of the pentacyclic triterpenes compounds which was tested and demonstrated the inhibitory activity of virus replication. In addition, according to Wzoniak et al. (2015) ursolic acid, a compound of pentacyclic triterpene of the ursane, has a structure that mimics asiatic acid and showed inhibitory activity on the protease of human immunodeficiency virus (HIV).

Asiatic acid is a natural pentacyclic triterpene that is found in plants, one of which is contained in the Centella asiatica L (Hashim et al., 2011). Asiatic acid has a triterpenoid scaffold with hydroxyl groups at the positions of $\mathrm{C} 2, \mathrm{C} 3$, and $\mathrm{C} 23$, as well as the carboxylic group at the $\mathrm{C} 28$ position ( $\mathrm{Li}$ et al., 2014). Modifications of the hydroxy and carboxylic groups and rearrangement of double bonds of asiatic acid result in higher binding affinity than asiatic acid binding to iNOS enzyme which has role in synthesizing Nitric Oxide (NO), one of the mediators of inflammation (Musfiroh et al., 2014).

The current antiviral management for COVID-19 in Indonesia are oseltamivir and favipiravir (Burhan et al., 2020). However, oseltamivir has antiviral activity by inhibiting neuraminidase which prevents the virus infecting the host cells (Kamali \& Holodniy, 2013), 
Table 1. Modification of the structure of asiatic acid (Musfiroh et al., 2014)

\begin{tabular}{|c|c|c|c|c|c|c|}
\hline \multirow{2}{*}{ Compounds } & \multicolumn{6}{|c|}{ Functional Groups Modification } \\
\hline & $\mathrm{C2}$ & $\mathbf{C 3}$ & $\mathrm{C23}$ & C11 & C13 & $\mathrm{C28}$ \\
\hline AA1 & $\mathrm{OH}$ & $\mathrm{OH}$ & $\mathrm{CH} 2 \mathrm{OH}$ & $\mathrm{H}$ & $\mathrm{H}$ & $\mathrm{H}$ \\
\hline AA2 & $\mathrm{OH}$ & $\mathrm{OH}$ & $\mathrm{CH} 2 \mathrm{OH}$ & $\mathrm{H}$ & $\mathrm{H}$ & $\mathrm{CH}_{3}$ \\
\hline $\mathrm{AA} 3$ & OAc & OAc & $\mathrm{CH} 2 \mathrm{OAc}$ & $\mathrm{H}$ & $\mathrm{H}$ & $\mathrm{H}$ \\
\hline AA4 & OAc & OAc & $\mathrm{CH} 2 \mathrm{OAc}$ & $\mathrm{H}$ & $\mathrm{H}$ & $\mathrm{CH}_{3}$ \\
\hline AA5 & OAc & OAc & $\mathrm{CH} 2 \mathrm{OAc}$ & Ene & Ene & $\mathrm{CH}_{3}$ \\
\hline AA6 & Oxo & Oxo & $\mathrm{COOH}$ & Ene & Ene & $\mathrm{CH}_{3}$ \\
\hline AA7 & Oxo & Oxo & $\mathrm{COOH}$ & Ene & Ene & $\mathrm{H}$ \\
\hline AA8 & Oxo & Oxo & $\mathrm{COOH}$ & $\mathrm{H}$ & $\mathrm{H}$ & $\mathrm{CH}_{3}$ \\
\hline AA9 & Oxo & Oxo & $\mathrm{COOCH} 3$ & Ene & Ene & $\mathrm{CH}_{3}$ \\
\hline AA10 & Oxо & Oxо & COOCH3 & Ene & $\mathrm{H}$ & $\mathrm{CH}_{3}$ \\
\hline AA11 & Oxo & $\mathrm{OH}$ & $\mathrm{CH} 2 \mathrm{OH}$ & $\mathrm{H}$ & $\mathrm{H}$ & $\mathrm{CH}_{3}$ \\
\hline AA12 & Oxо & Oxо & $\mathrm{CH}_{3} \mathrm{COOH}$ & $\mathrm{H}$ & $\mathrm{H}$ & $\mathrm{H}$ \\
\hline AA13 & Oxо & $\mathrm{OH}$ & $\mathrm{CH} 2 \mathrm{OH}$ & $\mathrm{H}$ & $\mathrm{H}$ & $\mathrm{H}$ \\
\hline
\end{tabular}

while SARS-CoV-2 does not have neuraminidase. In this study, affinity predictions were thus performed on asiatic acid as well as its derivatives and favipiravir against SARS-CoV-2 $\mathrm{M}^{\text {pro }}$.

\section{METHODS}

Preparation of SARS-CoV-2 $\mathrm{M}^{\text {pro }}$ and Asiatic Acid Derivatives Structures

The crystal structure of SARS-CoV-2 M $\mathrm{M}^{\text {pro }}$ (PDB code 6LU7) was obtained from Protein Data Bank (PDB) and the native ligand and water molecules were removed for molecular docking. Favipiravir and asiatic acid structures were downloaded from PubChem database and asiatic acid derivatives were designed using ChemDraw Ultra. The derivative structures of asiatic acid refer to previous work by Musfiroh et al, 2014 (AA1-AA13), in which the modification of structure occurs at C-2, C3, $\mathrm{C} 23, \mathrm{C} 11, \mathrm{C} 13$ and $\mathrm{C} 23$ with methylation, acetylation, rearrangement of double bond, oxidation of hydroxyl

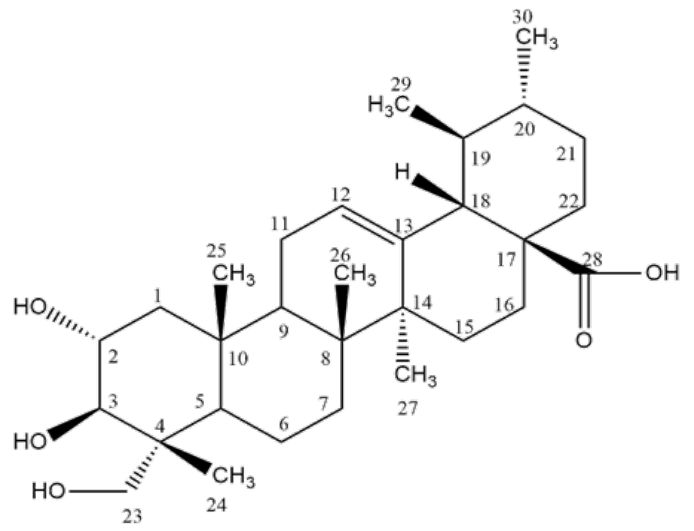

Figure 1. Asiatic acid structure group and combination of them (Figure 1 and Table 1). The ligands were optimized with MM2 using Chem3D pro and converted into the PDB format. For further analysis, SARS-CoV-2 $\mathrm{M}^{\text {pro }}$ and ligands were optimized and converted into PDBQT format using AutoDockTools.

\section{Active Site Identification}

The amino acid residues in the active site of SARSCoV-2 $\mathrm{M}^{\text {pro }}$ were identified using Discovery Studio.

\section{Validation of Molecular Docking Method}

Validation was performed using AutoDockTools by redocking the native ligand to SARS-CoV-2 $\mathrm{M}^{\text {pro }}$. The validation was conducted to find out the size and the coordinate of the grid box that will be used for molecular docking of test compounds.

\section{Molecular Docking}

Molecular docking for all compounds were performed using AutoDockTools. The grid coordinates were based on the native ligand position in the binding site of SARSCoV-2 M $\mathrm{M}^{\text {pro }}$. The site of affinity map was set to $70 \AA \mathrm{x}$ $70 \AA$ x $70 \AA$ with spacing between the grid points set to $0.375 \AA$ and coordinates of central grid point of maps were at $X=-9.732, Y=11.403, Z=68.925$. The molecular docking was performed by regulating the genetic algorithm parameters, using 100 runs of the GA criteria

\section{Visualization and Analysis}

The results were visualized and analyzed using Discovery Studio to find out the interactions that occur between ligand and SARS-CoV-2 M ${ }^{\text {pro }}$. Hydrogen bonds, hydrophobic interactions, other bonds that might occur, and the distances of the bonds were observed. 
Table 2. Amino acid residues in the active site of SARS-CoV-2 $\mathrm{M}^{\text {pro }}$

\begin{tabular}{lll}
\hline Types of Bond & Amino Acid Residues & Binding Distance $(\AA)$ \\
\hline Hydrogen & Phe140 & 3.19 \\
& His163 & 2.37 \\
& His164 & 2.80 \\
& Gly143 & 2.87 \\
& Gln189 & 2.89 \\
& Glu166 & 2.98 \\
Alkyl dan $\pi$-Alkyl & Glu166 & 2.83 \\
& Thr190 41 & 2.85 \\
& Met49 & 4.27 \\
& Pro168 & 4.73 \\
& Ala191 & 4.85 \\
& Leu167 & 4.54 \\
Carbon hydrogen & Met165 & 5.46 \\
& His172 & 4.57 \\
& Met165 & Leu141
\end{tabular}

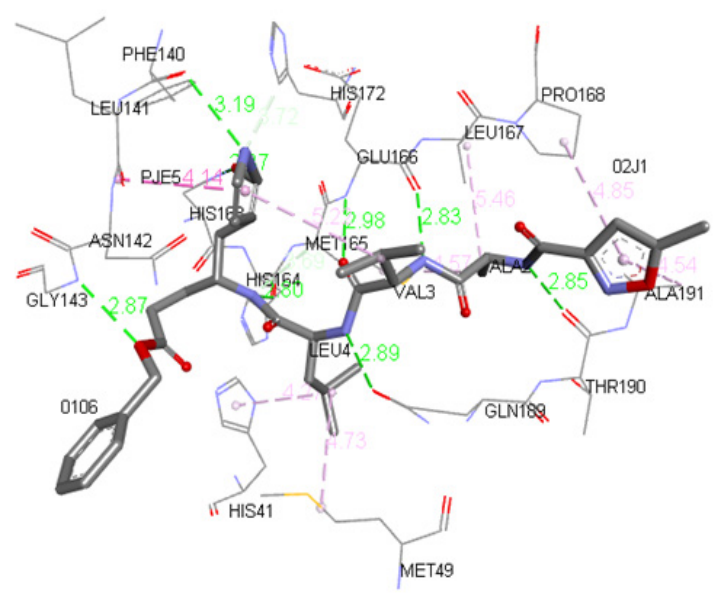

Figure 2. Interactions between the native ligand and SARS-CoV-2 M Mro $^{\text {pro }}$

\section{RESULTS AND DISCUSSION}

\section{Active site of SARS-CoV-2 $\mathrm{M}^{\text {pro }}$}

Analysis of the active site of SARS-CoV-2 $\mathrm{M}^{\text {pro }}$ was performed by visualizing the interactions that occur between the native ligand and SARS-CoV-2 $\mathrm{M}^{\text {pro }}$. Visualization was carried out using Discovery Studio to see the amino acid residues that interact with their native ligand therefore the active site of SARS-CoV-2 $\mathrm{M}^{\text {pro }}$ can be identified. From the visualization of SARS-CoV-2 $\mathrm{M}^{\text {pro }}$, several amino acid residues interact with the native ligand in the receptor active site (Figure 2). The results of visualization of interactions between ligand and receptor are shown in Table 2.

\section{Validation of Molecular Docking Method}

Method validation was conducted by re-docking the

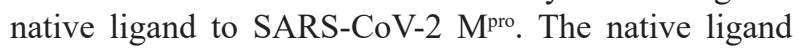
of SARS-CoV-2 with PDB code 6LU7 is N3. N3 acts as an inhibitor of SARS-CoV-2 $\mathrm{M}^{\text {pro }}$ by occupying the substrate binding site (Jin, et al., 2020). The validation results are shown in Table 3. Root mean square deviation (RMSD) with grid size of $70 \AA$ x $70 \AA$ x $70 \AA$ is in accordance with the terms of docking method. The validation results show the RMSD value $\leq 3 \AA$ meaning that the method used has met the expected criteria (Jain and Nicholls, 2008). Visualization of interactions using AutoDockTools showed three hydrogen bonds between the native ligand and Glu166, Gly143, and His163.

\section{Molecular Docking of Favipiravir against SARS-} CoV-2 Mro

The results of docking a drug molecule used as a treatment for COVID-19 in Indonesia nowadays (favipiravir) with SARS-Cov-2 $\mathrm{M}^{\text {pro }}$ are shown in Table 4. The docking of favipiravir against SARS-CoV-2 $\mathrm{M}^{\text {pro }}$ (Figure 3) has 
Table 3. Results of re-docking the native ligand to the active site of SARS-CoV-2 Mpro

\begin{tabular}{lllll}
\hline Compound & $\begin{array}{l}\Delta \boldsymbol{G} \\
(\mathbf{k c a l} / \mathbf{m o l})\end{array}$ & $\begin{array}{l}\text { Inhibition } \\
\text { Constant }(\boldsymbol{\mu M})\end{array}$ & RMSD $(\AA)$ & $\begin{array}{l}\text { Amino Acid Residues } \\
\text { (Hydrogen Bonds) }\end{array}$ \\
\hline N3 & -8.30 & 0.82 & 2.843 & $\begin{array}{l}\text { Glu166 } \\
\text { Gly143 } \\
\text { His163 }\end{array}$ \\
\hline
\end{tabular}

Table 4. Molecular docking results of favipiravir against SARS-CoV-2 $\mathrm{M}^{\text {pro }}$

\begin{tabular}{lllll}
\hline Compound & $\begin{array}{l}\Delta \boldsymbol{G} \\
(\mathbf{k c a l} / \mathbf{m o l})\end{array}$ & $\begin{array}{l}\text { Inhibition } \\
\text { Constant }(\boldsymbol{\mu M})\end{array}$ & $\begin{array}{l}\text { Amino Acid Residues } \\
\text { (Hydrogen Bonds) }\end{array}$ & $\begin{array}{l}\text { Binding } \\
\text { Distance }(\AA)\end{array}$ \\
\hline & & & Asn142 & 2.07 \\
& & & Phe140 & 2.24 \\
Favipiravir & \multirow{2}{*}{4.58} & \multirow{2}{*}{441.04} & Glu166 & 1.82 \\
& & & His16 & 2.32 \\
& & His163 & 1.83 \\
& & Ser144 & 2.79 \\
& & & Cys145 & 2.37 \\
& & Cys145 & 2.84 \\
\hline
\end{tabular}

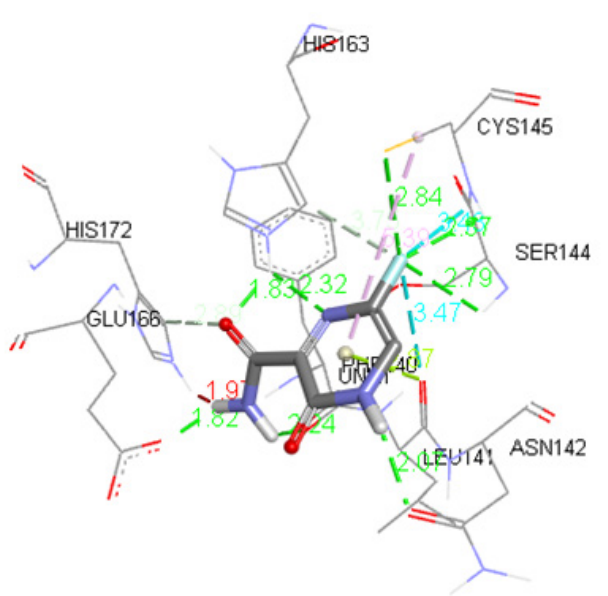

Figure 3. Interactions between favipiravir and SARS-CoV-2 $M^{\text {pro }}$

shown several hydrogen bonds (green dotted lines) between favipiravir and Asn142, Phe140, Glu166, His163, Ser144, and Cys145. When compared with the native ligand of SARS-CoV-2 $\mathrm{M}^{\text {pro }}$, favipiravir has similar interactions with Phe140, Glu166, and His163. Hydrogen bonds between favipiravir and SARS-CoV-2 $\mathrm{M}^{\text {pro }}$ occur through the bonding of hydrogen atoms in the primary amine group with Phe140 and Glu166 with distances of $2.24 \AA$ and $1.82 \AA$, respectively and with His 163 through bonds between oxygen and nitrogen atoms in favipiravir with distances of $1.83 \AA$ and 2.32 $\AA$, respectively. The docking results also showed that the $\Delta G^{0}$ needed for the interaction between favipiravir and SARS-CoV-2 $\mathrm{M}^{\text {pro }}$ was $-4.58 \mathrm{kcal} / \mathrm{mol}$ and the inhibition constant was $441.04 \mu \mathrm{M}$. Based on an analysis using
Discovery Studio, favipiravir tends to have hydrogen bonds because it has a lot of hydrogen bonds donors and acceptors, and this is supported by the fact that favipiravir has hydrogen atoms in primary and secondary amine groups as hydrogen bond donors and it also has tertiary amine groups, carbonyl and halogen (in the form of fluorine) which act as hydrogen bond acceptors. However, favipiravir has an unfavorable donor-donor bond with His 172 which indicates the repulsion between two atoms.

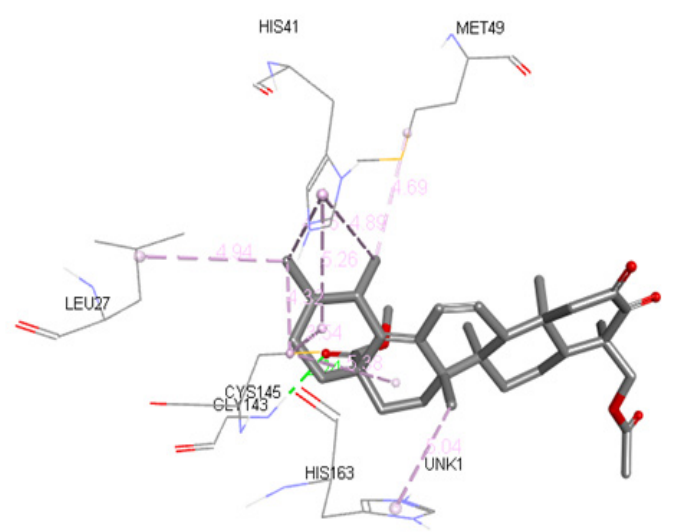

Figure 4. Interactions between AA9 and SARSCoV-2 Mpro

Molecular docking of Asiatic Acid and its Derivatives to SARS-CoV-2 $M^{\text {pro }}$

Molecular docking of asiatic acid (Figure 4) and its

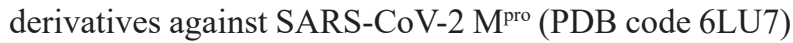
was carried out to predict the affinity of these compounds. The asiatic acid derivative structures refer to the 
Table 5. Molecular docking results of asiatic acid and its derivatives against SARS-CoV-2 $\mathrm{M}^{\text {pro }}$

\begin{tabular}{|c|c|c|c|c|}
\hline Compounds & $\begin{array}{l}\Delta G \\
(\mathrm{kcal} / \mathrm{mol})\end{array}$ & $\begin{array}{l}\text { Inhibition } \\
\text { Constant }(\mu \mathrm{M})\end{array}$ & $\begin{array}{l}\text { Amino Acid Residues } \\
\text { (Hydrogen Bonds) }\end{array}$ & $\begin{array}{l}\text { Binding } \\
\text { Distance }(\AA)\end{array}$ \\
\hline \multirow[t]{5}{*}{ AA1 } & -7.91 & 1.59 & Thr26 & 1.84 \\
\hline & & & Cys 145 & 2.28 \\
\hline & & & Glu166 & 2.49 \\
\hline & & & Gln189 & 1.96 \\
\hline & & & Gln 189 & 1.88 \\
\hline \multirow[t]{5}{*}{ AA2 } & -8.03 & 1.30 & Cys 145 & 3.17 \\
\hline & & & Cys 145 & 2.48 \\
\hline & & & Ser144 & 2.64 \\
\hline & & & Ser 46 & 2.86 \\
\hline & & & Ser46 & 1.85 \\
\hline \multirow[t]{2}{*}{ AA3 } & -8.10 & 1.15 & Thr26 & 1.90 \\
\hline & & & Cys145 & 2.51 \\
\hline \multirow[t]{3}{*}{ AA4 } & -8.24 & 0.91 & Cys 145 & 1.93 \\
\hline & & & Asn142 & 2.95 \\
\hline & & & His 163 & 1.94 \\
\hline \multirow[t]{2}{*}{ AA5 } & -10.15 & 0.03 & Gln192 & 2.36 \\
\hline & & & Gly143 & 2.19 \\
\hline AA6 & -8.52 & 0.56 & Gly143 & 2.19 \\
\hline \multirow[t]{3}{*}{ AA7 } & -7.99 & 1.39 & Asn 142 & 2.01 \\
\hline & & & Gly143 & 2.18 \\
\hline & & & Glu166 & 2.11 \\
\hline \multirow[t]{2}{*}{ AA8 } & -8.77 & 0.37 & Cys145 & 2.27 \\
\hline & & & Glu166 & 1.95 \\
\hline AA9 & -9.90 & 0.05 & Gly143 & 2.24 \\
\hline \multirow[t]{3}{*}{ AA10 } & -8.40 & 0.69 & Cys 145 & 3.03 \\
\hline & & & Ser144 & 2.44 \\
\hline & & & Thr45 & 2.95 \\
\hline AA11 & -9.05 & 0.23 & Asn142 & 2.24 \\
\hline \multirow[t]{4}{*}{ AA12 } & -8.54 & 0.54 & Thr26 & 2.25 \\
\hline & & & Cys 145 & 2.55 \\
\hline & & & Gly143 & 2.13 \\
\hline & & & Glu166 & 2.24 \\
\hline \multirow[t]{2}{*}{ AA13 } & -8.44 & 0.65 & His 41 & 2.00 \\
\hline & & & Asn142 & 1.77 \\
\hline
\end{tabular}


Table 6. Number of cluster of asiatic acid and its derivatives

\begin{tabular}{llll}
\hline Compounds & $\begin{array}{l}\Delta \boldsymbol{G} \\
(\mathbf{k c a l} / \mathbf{m o l})\end{array}$ & $\begin{array}{l}\text { Inhibition } \\
\text { Constant }(\boldsymbol{\mu M})\end{array}$ & Number of Cluster \\
\hline AA1 & -7.91 & 1.59 & $25 / 100$ \\
AA4 & -8.24 & 0.91 & $9 / 100$ \\
AA5 & -10.15 & 0.03 & $7 / 100$ \\
AA7 & -7.99 & 1.39 & $55 / 100$ \\
AA8 & -8.77 & 0.37 & $14 / 100$ \\
AA9 & -9.90 & 0.05 & $49 / 100$ \\
AA12 & -8.54 & 0.54 & $32 / 100$ \\
\hline
\end{tabular}

Table 7. Interactions of AA9 with the active site of SARS-CoV-2 M $^{\text {pro }}$

\begin{tabular}{lll}
\hline Types of Bond & Amino Acid Residues & Binding Distance $(\AA)$ \\
\hline Hydrogen & Gly143 & 2.24 \\
Alkyl dan $\pi$-Alkyl & His163 & 5.04 \\
& Cys145 & 3.54 \\
& Cys145 & 4.32 \\
& Cys145 & 5.38 \\
& Leu27 & 4.94 \\
Met49 & 4.69 \\
& His41 & 4.16 \\
& His41 & 4.89 \\
& His41 & 5.26 \\
\hline
\end{tabular}

previous study by Musfiroh et al (2014). Modification of the structure of asiatic acid was carried out in the active site of hydroxy groups $\mathrm{C} 2, \mathrm{C} 3, \mathrm{C} 23$, carboxylic group $\mathrm{C} 28$, and rearrangement of double bonds $\mathrm{C} 11$ and $\mathrm{C} 13$. Structural modifications were carried out as shown in Table 1 .

Molecular docking results showed that the interactions between asiatic acid with SARS-CoV-2 $\mathrm{M}^{\text {pro }}$ has more hydrogen bonds compared to all asiatic acid derivatives as shown in Table 5. Asiatic acid has hydrogen bonds with Thr26, Cys145, Glu166 and Gln189 and shows a similarity with the native ligand in terms of the interactions with Glu166 and Gln189. However, there are some derivatives of asiatic acid that did not have any interaction with amino acid residues that interact with the native ligand, including compounds AA2, AA3, AA10, AA11, and AA13. This made only compounds AA1, AA4, AA5, AA7, AA8, AA9 and AA12 as compounds that have the potential to inhibit SARS-CoV-2 $\mathrm{M}^{\text {pro }}$. On the other hand, despite having a hydrogen bond similar with the native ligand in Gly143, AA6 also has an unfavorable acceptor-acceptor bond which affects the stability of the compound activity. All unfavorable protein-ligand interactions will reduce the stability of the complex because they indicate the repulsion that occurs between 2 molecules or atoms (Dhorajiwla et al., 2019). Molecular docking results showed that asiatic acid and its derivatives have negative binding free energies, indicating that the receptor-ligand interaction take place spontaneously (Du et al., 2016). The results (Table 5) showed that all asiatic acid derivatives have lower binding free energies compared to asiatic acid which has $\Delta G$ value of $-7.91 \mathrm{kcal} / \mathrm{mol}$. However, based on binding free energy, AA5 is the most stable compound when binding to SARS-CoV-2 $\mathrm{M}^{\text {pro }}$ because the lower value of binding free energy indicates a higher level of stability when the ligand binds to the receptor, and this can cause stronger bonds to form. If the results of the molecular docking of asiatic acid and its derivatives are compared with favipiravir which has a $K i$ value of $441.04 \mu \mathrm{M}$ and a $\Delta G$ value of $-4.58 \mathrm{kcal} / \mathrm{mol}$, AA1, AA $4, \mathrm{AA} 5, \mathrm{AA} 7$, AA8, AA9 and AA12 have better potential in inhibiting the action of the main protease of SARS-CoV-2.

The selection of the most potential compound to inhibit SARS-CoV-2 $\mathrm{M}^{\text {pro }}$ was conducted further by looking at another factor, namely a number of clusters, which is the number of conformations formed when a ligand is docked to the active site of the receptor. In this study, each ligand was docked 100 times into the active site of the receptor, and the more conformations that are formed each time a ligand was docked, the more stable the ligand in the conformation. As shown in Table 6, AA5 has the lowest energy but also very low number of clusters (7/100), while AA7 has the highest number of 
clusters (55/100), but also a high value of binding free energy. In contrast, AA9 has higher energy than AA5 but also has a higher number of clusters (49/100) which is quite similar to AA7. This indicates that AA9 is much more stable compared with these compounds.

The results of docking AA9 to the active site of SARSCoV-2 $\mathrm{M}^{\text {pro }}$ can be seen in Figure 4 and Table 7, showing a hydrogen bond formed by oxygen atoms of AA9 with Gly143, with the distance of $2.24 \AA$. This bond occurs with the involvement of oxygen atom in the ester group at $\mathrm{C} 28$ of AA9. In addition, AA9 also has hydrophobic interactions between alkyl groups at $\mathrm{C} 29$ and $\mathrm{C} 30$ with Met49 and Cys145 and $\pi$-alkyl interactions between aromatic groups, C27, C29, and C30 with Leu27, His41, and His 163 .

\section{CONCLUSION}

Asiatic acid and its derivatives have shown higher binding affinities to SARS-CoV-2 main protease compared to favipiravir. Moreover, the strongest inhibition is shown by AA9 with $\Delta G$ value of $-9.90 \mathrm{kcal} / \mathrm{mol}$. AA9 has a structure modification from asiatic acid to oxo groups at $\mathrm{C} 2$ and $\mathrm{C} 3$, acetyl at $\mathrm{C} 23$, methyl at $\mathrm{C} 28$ and rearrangement of double bonds at $\mathrm{C} 12$. The interactions of AA9 with the active site of SARS-CoV-2 $\mathrm{M}^{\text {pro }}$ are through hydrogen bonds with Gly143 (distance of 2.24 $\AA$ ), hydrophobic interactions between alkyl groups at C29 and C30 with Met49 and Cys145, respectively, and $\pi$-alkyl interactions between the aromatic groups, C27, C29 and C30 in AA9 with Leu27, His41, and His163, respectively.

\section{ACKNOWLEDGMENT}

We would like to thank to research teams of computational laboratory of Faculty of Pharmacy Universitas Padjadjaran Bandung for their support to this research.

\section{REFERENCES}

Burhan, E., Susanto, A.D., Nasution, S.A., Ginanjar, E., Pitoyo, C.W., Susilo A., Firdaus, I., Santoso, A., Juzar, D.A., Arif, S.K., Wulung, N.G.H.L., Damayanti, T., Wiyono, W.H., Prasenohadi, Alfiatin, Wahyudi, E.R., Tarigan, T.J.E., Hidayat, R., \& Muchtar, F. (2020). Protokol tatalaksana COVID-19. Jakarta: PDPI, PERKI, PAPDI, PERDATIN, dan IDAI.

Dhorajiwala, T.M., Halder, S.T., \& Samant, L. (2019). Comparative in silico molecular docking analysis of 1-threonine-3-dehydrogenase, a protein target against african trypanosomiasis using selected phytochemicals. Journal of Applied Biotechnology Reports, 6(3), 101108.
Du, X., Li, Y., Xia, Y.L., Ai, S.M., Liang, J., Sang, P., Ji, X.L., and Liu, S.Q. (2016). Insights into proteinligand interactions: mechanisms, models, and methods. International Journal of Molecular Sciences, 17(2), 144.

Hashim, P., Sidek, H., Helan, M.H., Sabery, A., Palanisamy, U.D., \& Ilham, M. (2011). Triterpene composition and bioactivities of centella asiatica. Molecules, 16, 1310-1322.

Huang, C., Wang, Y., Li, X., Ren, L., Zhao, J., Hu, Y., Zhang, L., Fan, G., Xu, J., Gu, X., Cheng, Z., Yu, T., Xia, J., Wei, X., Wu, W., Xie, X., Yin, W., Li, H., Liu, M., Xiao, Y., Gao, H., Guo, L., Xie, J., Wang, G., Jiang, R., Gao, Z., Jin, Q., Wang, J., \& Cao B. (2020). Clinical features of patients infected with 2019 novel coronavirus in wuhan, china. The Lancet, 395, 497-506.

Jain, A.J. and Nicholls, A. (2008). Recommendations for evaluational methods. Journal of Computer-Aided Molecular Design, 22, 133-139.

Jin, Z., Du, X., Xu, Y., Deng, Y., Liu, M., Zhao Y., Zhang, B., Li, X., Zhang, L., Peng, C., Duan, Y., Yu, J., Wang, L., Yang, K., Liu, F., Jiang, R., Yang, X., You, T., Liu, X., Yang, X., Bai, F., Liu, H., Liu, X., Guddat, L.W., Lu, W., Xiao, G., Qin, C., Shi, Z., Jiang, H., Rao, Z., \& Yang, H. (2020). Structure of $M^{\text {pro }}$ from COVID-19 virus and discovery of its inhibitors. Nature, 582, pages 289-293

Kamali, A. and Holodniy, M. (2013). Influenza treatment and prophylaxis with neuraminidase inhibitors: a review. Infect Drug Resist, 6, 187-198.

Musfiroh, I., Puspitasari, I., Muhtadi, A., Kartasasmita, R.E., \& Surantaatmadja, S.I. (2014). Acetylation of asiatic acid and its hepatotoxicity prediction. ICCST. 3, 45-48.

Ozdemir, O. (2020). Coronavirus disease 2019 (COVID-19): diagnosis and management (narrative review). Erciyes Medical Journal, 42(3), 00-00.

WHO. (2020). Naming the coronavirus disease (COVID-19) and the virus that causes it. Available at: https://www.who.int/emergencies/diseases/novelcoronavirus-2019/technical-guidance/naming-thecoronavirus-disease-(covid-2019)-and-the-virus-thatcauses-it

Wozniak, L., Skapska, S., \& Marszalek, K. (2015). Ursolic acid - a pentacyclic triterpenoid with a wide spectrum of pharmacological activities. Molecules, 20, 20614-20641. 
Yang, L., Wen, K.S., Ruan, X., Zhao, Y.X., Wei, F., \& Wang, Q. (2018). Response of plant secondary metabolites to environmental factors. Molecules, 23(4), 1-26.

Zhao, C., Xu, J., Zhang, Y., Zhao, L., \& Feng, B. (2014). Inhibition of human enterovirus 71 replication by pentacyclic triterpenes and their novel synthetic derivatives. Chemical and Pharmaceutical Bulletin, 62(8), 764-771.

Zhu, N., Zhang, D., Wang, W., Li, X., Yang, B., Song, J., Zhao, X., H, B., S, W., Lu, R., Niu, P., Zhan, F., Ma, X., Wang, D., Xu, W., Wu, G., Phil, G.F.G.D., \& Tan, W. (2020). A novel coronavirus from patients with pneumonia in china, 2019. The New England Journal of Medicine, 382, 727-733. 